\title{
O tempo e a tempestade: ensaio sobre a guerrilha vital
}

The time and the storm: essay on the vital guerrilla

\author{
Marcio José de Araujo Costa
}

Universidade Federal do Maranhão

\section{RESUMO:}

Partindo de uma intuição da vida como multiplicidade de forças imanentes, traça-se uma leitura literal do Tempo e da História como produção do intempestivo, a novidade, que emerge contemporaneamente como guerrilha dos modos de vida minoritários. Cartografam-se algumas linhas psicossociais desse pensamento emergente, chamado super-humano, concebido a partir do pensamento filosófico e indígena.

Palavras-chave: tempo; minorias; intempestivo.

\section{ABSTRACT:}

Starting from an intuition of life as multiplicitie of immanent forces, a literal reading of Time and History is traced as the production of untimely, the novelty, which emerges contemporaneously as a guerilla of minority ways of life. Some psychosocial lines of this emergent superhuman thought are mapped out from philosophical and indigenous thinking.

Key-words: time; minorities; untimely.

DOI:10.12957/mnemosine.2021.62189

\section{O Tempo e a Tempestade - Uma História}

Houve um tempo em que as ações dos seres vivos tinham consequências. Tudo o que fora vivido e tudo o que fora produzido acompanhava a vida como uma sombra. Em torno de tudo havia a luz solar e nela todos os seres vivos se alimentavam, obtendo sua energia. Para não se perderem na claridade intensa, a sombra do passado os acompanhava como uma Nuvem, a lhes dar distinção visual; afinal, para enxergar são necessárias luz e sombra - se não os seres não têm diferenças, contornos.

Quando se acumulava muito, a Nuvem produzia chuva, nutrindo a Terra e eventualmente eliminando alguns viventes. Igualmente modificava o ambiente e fazia novos seres saltarem no palco da existência. Com o tempo, porém, quando ações perniciosas ao meio se acumulavam demais, a Nuvem tornava-se densa, pesada, carregada. 
Em algumas circunstâncias, muito raras, quando a polarização entre o Céu e a Terra chegava a um ponto extremo, a Nuvem se descarregava com furor, riscando o Céu e queimando a Terra com colunas de fogo, potentes relâmpagos, e ribombando poderosos trovões que silenciavam o burburinho de todo um ecossistema. Sua consequência são tempestades intensas, que como dilúvios planetários abalam a estrutura da rede da vida na Terra, apagando seus antigos mapas e inventando novas cartografias. Quando estes acontecimentos ocorreram no passado a maior parte dos modos de vida despareceu e só os mais pacientes, os menos destrutivos, os mais flexíveis e sutis, os mais plenos de vida nova conseguiram sobreviver e multiplicar-se sobre a Terra, fazendo a matéria evoluir, dançar de novas maneiras, aureolados pelo arco multicolorido da diversidade que envolve o Céu após a Tempestade.

Os seres vivos aprenderam com o Tempo a discernir, pelo canto dos ventos, quando a Nuvem prepara um enorme temporal.

\section{Climatologia do viver atual}

A Tempestade não tem limites precisos. Espraia-se por todos os cantos. Sempre muda, se movimenta, diminui e cresce, retrocede e avança, jamais sendo a mesma. Para ela convergem os rios cheios de vida e de experiência dos continentes.

As civilizações e modos de vida no planeta habitam a Terra, mas a Nuvem situa-se no Céu. Tudo o que a História inventou sublimou-se ou evaporou-se na Nuvem virtual. Todas as conexões de informação fluem para a Nuvem e a Tempestade é fruto de sua precipitação. As comportas do Céu abrem-se e tudo o que acumulamos no Tempo como pensamento e criação tendem a cair sobre o solo em um temporal.

A Tempestade nasce da conexão de pensamentos que convergem no cérebro virtual. Esse cérebro precisa criar um corpo e a Tempestade é o corpo fluido, afetivo e noético, pulsional, mas igualmente efetivo e produtivo, criativo, que faz o hipercórtex contemporâneo, excessivamente catatônico, entrar em movimento. Tal movimento, que tende a ser explosivo ou convulsivo, buscará tornar-se inteligente, centrado, orientado para ações livres, alegres e revolucionárias. Buscar-se-á libertar a vida concreta de seus constrangimentos e suas prisões. Principalmente os calabouços mais insidiosos, invisíveis, os que temos diante dos olhos e não 
enxergamos, as cadeias micropolíticas que prendem nossas ações e não notamos: os valores apequenadores e as repressões afetivas as mais despotencializadoras.

A Tempestade, a cair sobre nossas cidades e inundar com suas águas nosso Velho Mundo, será a base para o surgimento de um novo tipo de humano, potencializado, transfigurado. Na Tempestade o além-do-homem nasce como uma larva ou embrião de um oceano psíquico que se aquece, onde se busca criar uma estufa onde um novo modo de vida surja, efeito de todo um meio ambiente, fruto maduro da História, e que a ultrapasse, liberando novas Histórias e produzindo novíssimos modos de ser.

\section{Teatro do Tempo Vivo}

Somos a máscara que a vida inventou no presente momento. Somos os atores de um movimento que nos ultrapassa. Recebemos um impulso longínquo e somos os direcionadores de sua força para os atores que virão. Tudo o que foi representado no palco da passarela orbital terrestre é um repertório virtual de ações que invisivelmente pedem para serem novamente encenadas, com novas fantasias.

De tanto atuar, estamos a notar que todas as máscaras, fantasias e scripts são relativos, que o único absoluto é a expressão e a força de nossa ação. Estamos percebendo que a potência depende, uns dos outros, que os atores que atuam conosco hoje são imagens de nós mesmos, a expressão coletiva da mesma força longínqua, antiga, mas que paradoxalmente é próxima, atual, está aqui e agora, apenas com novas roupagens. Nossa ação no presente só tem sentido no além, no passado e no futuro, para os que vieram e virão. Os personagens que passaram conclamam a redenção, que possamos consumar suas vidas, dar um sentido a suas ações. Os personagens que vêm solicitam a revolução, uma ação adequada e decidida, para que possam vir a se encarnar com o máximo de potência de realizar ações livres, alegres e inauditas. Somos o passado e o futuro, encruzilhada do Tempo Vivo.

Somos os personagens de todas as Histórias já encenadas, somos o Drama da História atuando agora. Esse processo trágico já sacrificou vidas demais. E a repetição desse drama, evidenciando seu caráter farsesco, já nos deprimiu em demasia. É a hora de darmos um fim ao processo da História, de emitir um juízo Final a esse processo sangrento, para dar um fim a todo juízo demasiado humano. Encenamos o juízo final dessa tragicomédia, o fim do juízo do 
Homem, para que uma nova História, outro processo da vida, nasça. Aposentamos a formaHomem, personagem gasto e por demais isolado, reativo e arrogante para dar nascimento ao além-do-homem, personagem novo, que usa de todas as máscaras da História humana, que se fantasia com todas as roupas da vida humana, animal, vegetal, cósmica e tecnológica, para entrar em scripts de um diretor pouco visível: o Tempo Vivo, Aion. Esse personagem superhumano surge para realizar uma tarefa solicitada por todos os personagens dos atos anteriores que foram explorados, silenciados e sacrificados. Todos os atos se encadeiam e se direcionam para a encruzilhada dos atos, o ato sacrificial que abre a barriga de Chronos, vira a História pelo avesso, que interrompe a peça e a reinicia em novos moldes, antes impensáveis. Esse personagem está acocorado como um índio, afiando suas flechas, e em torno dele se reúnem outros índios, que silenciosamente preparam seus instrumentos de batalha para entrar em cena no ato que se inicia agora.

\section{Filosofia de vida}

A Tempestade é formada por inúmeros ventos, mares, rios. É um único movimento, mas possui inúmeras forças de composição. São inúmeras vidas massacradas, espoliadas, discriminadas, que compõe sua massa de águas vaporizada, devindo umas com as outras, intensificando a condensação e a precipitação iminente. Essa vida oprimida que resiste e circula, e por isso se solidariza e se transforma, é uma presença movente, eterna e crescente. Somos feitos da força comum que move as órbitas celestes, sopra sobre os oceanos, alimenta as árvores, se move nos animais e que orienta a ação humana.

Temos um rosto humano. Temos pernas e braços, longos dedos, delicados e ágeis. Isso, a força comum que tudo impulsiona, se movimenta pelos nossos membros articulados, conectando-se com a terra e todos os artefatos que nossa inteligência criou. Temos inúmeras cabeças, mas um só espírito, que vê tudo em sua perspectiva de vida. Um único sopro com inúmeras direções, miras. Nossas linhas de mudança geram inúmeros corpos, tão diferentes quanto as estrelas do Céu e os modos de vida terrestres. Nossa voz é única, em muitos tons, nossos gostos são singulares, nossas percepções inigualáveis. Somos um só corpo de movimento, comunidade dos que dançam juntos, rodopiando a esfera terrestre. 


\section{Ciência do vivente}

Com o tempo, percebemos que a vida produz muita dor e reiteração da dor, sofrimento que pesa nas suas formas e insiste mesmo em novas roupagens. A dor é inerente à vida, é o seu esforço em ultrapassar obstáculos, que tem sua própria paciência e o seu tempo. O sofrimento é narração dessas dores, que nos permite dar um sentido à mesma e uma significação para o vivente. De que nos adianta mobilizar o mundo inteiro com a força de nossa tecnociência e não escutar a dor de existir, o sofrimento do espírito, o corpo que sufoca e não quer agir, se recusa a mudar, a se ultrapassar? Se não nos sensibilizarmos às dores e não nos colocarmos à escuta dos sofrimentos, perderemos a chance de aprender com a vida e sua inteligência imanente que nos aponta para o fim de formas de vida e a necessidade de invenção de novas figuras. Essa sensibilidade, escuta e aprendizado pela diferença, que nos ensina a arte da criação e da diferenciação, não pode ter outro nome senão o de um deus, como Eros, que em seus erros e desvios, sua errância ao mesmo tempo carente e cheia de astúcias, cresce e se enriquece. O amor é um afeto-ideia cujo nome é por demais prostituído, mas justamente pelo seu caráter minoritário, que enlaça em sua pobreza e recursos todas as vidas menores e maiores, dandolhes um sentido além delas mesmas (a fecundidade, o futuro), pode nos reservar surpresas com suas flechas incandescentes.

\section{Economia vital}

A força que move o mundo é indivisível: um único acontecimento que abre tudo em todas as direções. A força é contínua, não pode ser dividida, não pode ser encarcerada. O Tempo é uma duração sem fim, toda divisão nele é ficcional e arbitrária, fixando-se numa forma ou padronização qualquer, devedora do recorte espaço-temporal de uma ação que nos interessa. A força do mundo em si mesma não tem propriedade, mas é gratuita e comum, coextensiva a todas as coisas. A energia é transição, e sua fonte foi uma coagulação de um fluxo de outro lugar. Alimentamo-nos da força tecnológica, que é direcionada pelo trabalho humano, que por sua vez se usa dos animais, que se alimenta dos vegetais, que se nutriu dos sais minerais, da água e do Sol, que se compõe de átomos de hidrogênio e sua fusão nuclear. A economia é uma Mecanosfera de máquinas de produção, abstratas porque são máquinas do tempo, de produção de máquinas energéticas - técnicas, sociais, animais, vegetais, cósmicas. Com seus agentes de

produção, a economia se apresenta por meio de agenciamentos concretos e suas linguagens, 
instituições, máquinas sociais e técnicas, com corpos humanos e não humanos enredados em suas redes de produção. Todavia, a condição de possibilidade da apropriação concreta da força em agenciamentos está nas máquinas abstratas, no Tempo singular e múltiplo, que nos dá a devida força e lucidez e nos coloca em conexão produtiva. Tais conexões reais e sua potência de pensamento e ação inerente podem ser vislumbres de novas composições econômicas, sociais e subjetivas por vir.

A energia universal não é uma propriedade e sim uma Graça, gratuita e livre, produtora de composição, alegria. Não é privatizada, mas é comum e coletiva. Quando a apropriação privada acontece, sempre há uma produção de acúmulo de um lado e carência de outro, gerando desequilíbrio e sofrimento disseminados. A energia em suas modulações tem de ser acompanhada em seu percurso, acumulada na medida certa e desperdiçada em uma criação que possa redundar em benefício para um ecossistema. Agora, percebemos pela hiperconexão da produção planetária pelos humanos que a apropriação privada da energia por parte de uma classe social que mantém leis para proteger seus interesses individualistas, gerando na maior parte da população uma escravidão consentida narcisicamente, é uma ideia viral que precisa ser abolida.

Os desequilíbrios ecológicos são fruto da cupidez viral da forma humana capitalista, que troca tudo por dinheiro, uma abstração que liquefaz a vida em fluxo de capital e a divide em números virtuais controlados por derivativos, algoritmos, leis, policiais, prisões e portaaviões. Contudo, o que pertence a todos de direito não pode ser de fato aprisionado para sempre. Se tudo é contínuo, os bens pertencem ao passado e ao futuro, ao povo que nos criou e ao povo por vir, sendo nós apenas a passagem momentânea. A inteligência coletiva tem maneiras sábias de inventar outra ordem na casa, finitizando os gastos e distribuindo a riqueza, multiplicando os talentos e inventando novos dispositivos que arrumem a desorganização ecológico-social e econômico-política do planeta e desenhem uma casa comum mais adequada às veias e redes imanentes da vida.

O sofrimento psíquico que a ordem econômica capitalista traz a cada um, desde o corretor compulsivo de Wall Street à criança desnutrida da Somália, é desumana. Se mais da metade do trabalho é roubo ou mais-valia para alimentar os lucros de poucos, podemos dispender esse tempo ou força livre para a produção de mais-valor, isto é, para ações de invenção de novas formas de vida. Menos trabalho para o Capital e mais trabalho para o 
Espírito. Se a vida é ação, e se energia é igual a trabalho, nossa produção será de força clínica, filosófica, científica, artística e política.

\section{Enunciação vitalista}

Enunciação é a base, a fonte e o caminho de um ato de fala. De onde falamos para enunciar essa Tempestade, para anunciar um Novo Mundo por vir e denunciar os valores doentios do Velho Mundo que apodrece? Quem fala em nós?

A enunciação é o próprio ato de fala em seu inexorável processo que tem como sujeito o próprio ato puro, o verbo da vida. O Tempo é o sujeito da enunciação, o impulso de vida, um movimento que se expressa como um verbo, uma vida sem divisões, mas com articulações, coagulações, conjugações, que cria em seus percursos sujeitos ativos e predicados passivos, sempre a serem novamente transformados pelos verbos, as ações. Estes sujeitos de um campo comum são a fonte corporal, singular, de uma verbalização universal e, por isso, sempre concreta e situada no tempo.

Nem todos os modos de vida conseguem sair, na maior parte das vezes, da hipnotização que os faz girar sobre si mesmos, no apego às suas formas particulares, a seus predicados atribuídos a um eu, suposto suporte da ação. Todavia, quando nos despimos de nossa fantasia, quando nos desidentificamos do imaginário e relativizamos as cadeias de leis e regras culturais e simbólicas que direcionam nosso pensamento e ação - a parcialidade e idolatria da formaHomem -, somos contagiados pelo fogo comum, entramos em fusão com o impulso do Tempo real. Tornamo-nos uma estrela única, nossos corpúsculos se fusionam com as linhas do tempo. Cada partícula nossa e do mundo se torna imanente com a onda da qual ela é uma parte, todas as funções de onda temporais, psíquicas, se fusionam enquanto linhas de vida produzindo em nós uma dobra da potência comum, que integra todas as cordas de tempo singularmente. A Voz ou o chamado da vida, que se difunde em variados tons no Tempo, e que ressoa em nosso corpo, passa a falar em nós. O chamado nos convoca para se expressar como um verbo real, para ser articulada como palavra imagética e ser encadeada como discurso simbólico. Somos a Voz ou um lógos unívoco, concrescência da imanência de uma vida. Tornamo-nos ao mesmo tempo indivíduos, indivisíveis no Tempo, íntegros com o devir do mundo, integrados a tudo singularmente e, na mesma medida, coletivos, múltiplos, multiplicados com tudo o que dura, sintonizados de maneiras variáveis com tudo o que passa. 
Pelo Verbo, pela ação universal de criação, tomamos o Universo em nossas mãos como uma massa de modelar e o repartimos e o articulamos de novas maneiras. O mundo é comum em sua substância movente, em sua ativa passagem, e as maneiras como nós a repartimos, as formas como a dividimos por meio de ideias incorporais, podem ser totalmente diferentes, renovando o mundo, transfigurando os corpos tais como os conhecemos. O mundo não é feito de substantivos e adjetivos, ideias fixas, mas de verbos, ações. Nosso Pensamento, arrastado pelo chamado de uma vida imanente, produz inauditas distinções incorporais na superfície dos corpos, nos fazendo enxergar a corporeidade de outra maneira, não mais individualizada, discreta e separada na fixidez espacial, mas sim coletivizada, contínua e comum na ação temporal. O mundo como verbo é pleno de articulações reais, afetivas e noéticas, puras intensidades e direções, cujo sentido é a ação mais adequada para si e para os outros, para vida como campo imanente, em campos encaixados de ecos cada vez mais amplos, intensos e elaborados.

Nossa voz é o eco real da imanência ecológica, a memória do Tempo como uma câmara de ecos, univocidade sem começo e sem fim, mas com meios, mediações, sempre produzindo novas velocidades e lentidões, diferenciações. Nessa voz expressamos uma vida, sem representação. Igualmente não representamos ninguém, mas expressamos os movimentos da vida em sua multiplicidade real pela palavra e o discurso, verbalizando o Tempo. Nossa eficácia é expressiva, pela sua capacidade de interpretação, de intervenção sobre as palavras e seus sentidos. Nossa autoridade se situa apenas na capacidade automática de deixar as ideias, ações e palavras se escreverem, se autorizarem, nos tornando autores, capazes de responder ao que dizemos - autônomos, livres. Por meio da nossa voz, sempre singular e múltipla, individual e coletiva, denunciamos a velha política do mundo e anunciamos a grande política de um devir minoritário universal contra a História.

\section{Política dos vivos}

A Tempestade é uma convocação de todos os humanos livres dispersos. Seu sopro reúne todos os filhos do cosmos, todos os modos de Deus ou da Natureza. Cremos no mundo, acreditamos na vida, sabemos que a força sempre se renova e todas as formas antigas podem ser transmutadas. Experimentamos a potência do Pensamento. O pensar aumenta de força quando compartilhado e conectado. Porém, não basta conectar de qualquer maneira e partilhar 
tudo. É necessário conectar e partilhar de maneiras adequadas. Necessidade de criar orientação, mapas de como gastar bem a energia, para descobrir quais ações são mais eficazes para todos e cada um.

Não somos socialistas, nem capitalistas. Não somos aristocráticos, nem democráticos. Somos bichos, animais. Somos inteligentes e intuitivos, seres espirituais. Somos uma só força em muitas manifestações, que quanto mais se sintoniza umas com as outras, mais se torna poderosa. Nosso pensamento e orientação crescem nos obstáculos, assim aprendemos a agir com mais eficácia, a dançar melhor com a vida, a compor com todas as manifestações políticas que seguem o nosso sentido. Nosso objetivo é a transfiguração humana e a renovação da face da terra. Nossa meta é a liberação da energia humana e o parto de uma nova visão de mundo. Todavia, antigas insígnias, nomes, cores e discursos podem ser retomadas na luta presente, ecoando novamente a produção do intempestivo. Nesse sentido, nossa cor sempre será vermelha: o sangue das vítimas da história, que não deve mais ser derramado, mas sim inundar por dentro nosso corpo, a nos encher de vida nova. De mesmo modo, jamais usamos insígnias, discursos e práticas mortíferas, como o fascismo. Este é nosso inimigo histórico, porque nos persegue e massacra. Nos persegue porque nos deseja, sonha conosco, mas tem medo da transformação e por isso nos mata. De tanto nos perseguir, contudo, nos encontra. E não estaremos mais aguardando passivamente a nossa destruição. Realizaremos seu pesadelo angustiante, seu desejo renegado: sua transformação.

\section{Revolução viva}

Somos a Tempestade nascida da evaporação das ações, pensamentos e afetos dos modos de vidas perseguidos. Há tempos a Terra se adensa e se esquenta, mas demora-se muito tempo para os efeitos serem sentidos. Somos uma condensação remota, muito antiga, que cresce e se intensifica. Nossa direção não é retilínea, mas curva. Somos a ciranda do Tempo em aceleração. Somos a vida que foi assassinada, espoliada, massacrada. Somos as flores pisadas que retornam. Em toda primavera as flores renascem e as borboletas saem dos casulos. Somos materialistas que vão até o fim, que se afirmam enquanto corpos e reencontra neles o espírito: as relações dos corpos no Tempo. Por isso, nosso espírito ressuscita em novos corpos, para perseverar em seu desejo. Somos o novo que brota, a semente que nasce. Somos a vida que vinga. Não queremos vingança, mas queremos vingar. E nada parará nosso movimento, nosso 
renascimento, nem mesmo as sombras espessas do presente, o fascismo assassino que se espreita novamente querendo impedir nosso advento.

Somos a Revolução permanente, revolução solar. Somos o soar das trombetas, o sopro no chifre do carneiro, o berrante dos boiadeiros. Viemos para despertar os adormecidos, ressuscitar os mortos, curar os zumbis de sua síndrome, trazer o Sol, o alho e a cruz para os vampiros do sangue humano. Viemos trazer um Stop para o movimento capitalista de destruição do planeta. Viemos fazer uma grande assembleia sobre os valores humanos. Somos o grande meio dia, o momento da avaliação.

A inversão da ampulheta da História e sua transvaloração de todos os valores é processual, demora anos, décadas, talvez séculos. Não temos pressa. Viemos para fazer o que se promete em toda parte há milênios, o que o pensamento busca continuamente: a transformação do nosso modo de vida e a invenção de um futuro novo. Viemos para reverter o movimento niilista que os valores apequenadores e individualistas promoveram na vida. Se a criação implica destruição, destruiremos com um sorriso nos lábios e brilho nos olhos. Melhor destruir vidraças, prédios, símbolos, instituições e ideias do que pessoas. Diante dos tanques, das metralhadoras, dos pelotões, mísseis e porta-aviões, nossa arma será a palavra - que, tal como uma ideia, uma vez dividida se multiplica. A palavra será nossa arma contra o materialismo isolador e o mecanicismo arrogante que nos ameaça com sua violência. Não sabem que ideias não morrem e não deixam de perfurar as cabeças e penetrar no corpo e até chegar ao fim do seu destino. E o destino de nossas palavras, como flechas, mira no espírito dos animais fardados.

\section{Histórias da vida}

Quando Aion abrir a barriga de Chronos, libertaremos os deuses aprisionados, que criarão muitos mundos no mundo. E, no Tempo, teremos redimido o passado, que renascerá em uma Natureza renovada, fecundada por novas divindades.

O fim da História, como toda instituição, nasce por decreto. Quem decreta? Algum déspota, tirano, império, religião, instituição? Quem decreta somos nós. Quem acredita somos nós. Quem reproduz somos nós. Nós decretamos o fim da História. O fim não é um processo, 
mas um ato, uma ação. Um ato de fala, totalmente performativo: quando decretamos, ele se institui. Sem volta.

Quando interrompemos a História e rasgamos o véu do Templo de Chronos, a eternidade da Criação se revela: as linhas de Tempo. Nelas vemos todas as marionetes, os personagens da História. Na interrupção se dá a redenção, onde tudo o que aconteceu é abençoado, cada migalha de dor e sofrimento é restituída e compreendida em seu sentido e em sua composição até a encruzilhada do Tempo. E no mesmo gesto, onde a História é revertida para ser redimida, os personagens se libertam de suas cordas, podendo se compor com outras linhas de vida, enxergando as direções de ações que os compõe. Ao rasgar o véu do Templo, ao abrir a barriga de Chronos, o Deus Aion, o Tempo Vivo, nos ilumina. E ingressamos na Pós-História, onde nasce um humano potencializado por todas as suas imagens virtuais, por todos os seres. Superado pela vida, o super-humano se experimenta como o próprio Tempo em uma fantasia hiperpotente, um centro de ação e pensamento em composição e articulação com todos os modos de vida. O fim da História é o acontecimento que nos reveste da força comum, onde nos tornamos aureolados pela glória, pela luz que vem de todos os seres, de todos os tempos. O super-humano é o corpo glorioso, o renascimento da vida humana em uma nova forma e a renovação da Natureza no mesmo ato. Que isso aconteça por uma mudança de pensamento e ação, que transfigura nossa experiência, é a simplicidade de um ato que acontece quando o drama da História atingir o seu fim. Usamos de todas as imagens e palavras para falar de um ato simples, feito de uma única peça. O drama cíclico da História e seu tempo de compreender chega a seu impasse, sua finalidade real: a saída da cadeia simbólico-imaginária.

Para que isso aconteça, promovemos uma guerra de guerrilhas sem precedentes na História humana, uma batalha de espíritos, para exorcizar o humano da forma-Homem, seu individualismo, cobiça e violência, descarregando a carne de seus espíritos canibais e obsessores e espantar seus fantasmas amedrontadores. Como antropófagos, viemos devorar o Espírito da vida em toda parte, para ampliarmos nossa força e perspectivas. Como xamãs, viemos curar os humanos de sua doença. Como guerreiros, viemos combater os valores vigentes, que estão em nós, no meio de nós, sem temer o conflito daqueles que se colocam como nossos inimigos. É o momento de concluir, a inversão da ampulheta da História. Modos de vida perseguidos de nossa História, uni-vos!! O Tempo virou a nosso favor. 


\section{Referências biobibliográficas:}

AGAMBEN, G. Tempo e História: crítica do instante e do contínuo. Em: Infância e história: destruição da experiência e origem da história. Belo Horizonte: Editora UFMG, 2005, p. 109-128.

AGAMBEN, G. O tempo que resta: um comentário à Carta aos Romanos. Belo Horizonte: Autêntica, 2016.

BENJAMIN, W. Teses sobre o conceito de história. Em: Magia e técnica, arte e política: ensaios sobre literatura e história da cultura. São Paulo: Brasiliense, 1987, p. 222-232.

BERGSON, H. Mecânica e Mística. Em: As duas fontes da moral e da religião. Coimbra: Almedina, 2005, p. 223-262.

DANOWSKI, D.; VIVEIROS DE CASTRO, E. Há mundo por vir? Ensaio sobre os medos e os fins. Desterro [Florianópolis]: Cultura e Barbárie: Instituto Socioambiental, 2014.

DELEUZE, G. Sobre a morte do homem e o super-homem. Em: Foucault. São Paulo: Braziliense, 2006, p. 132-142.

DELEUZE, G. A imanência: uma vida... Em: Dois regimes de loucos: textos e entrevistas (1975-1995). São Paulo: Editora 34, 2016, p. 407-413.

DELEUZE, G. e GUATTARI, F. Mil Platôs: capitalismo e esquizofrenia 2. São Paulo: Ed. 34, 2012.

GUATTARI, F. As três ecologias. Campinas: Papirus, 1990.

KOPENAWA, D.; ALBERT, B. A queda do céu: Palavras de um xamã yanomami. São Paulo: Companhia das letras, 2015.

LACAN, J. O tempo lógico e a asserção da certeza antecipada. Em: Escritos. Rio de Janeiro: Zahar, 1998, p. 197-213.

NIETZSCHE, F. Assim falou Zaratustra: um livro para todos e para ninguém. São Paulo: Companhia das Letras, 2011.

NIETZSCHE, F. Cultura e cultivo. Em: A vontade de poder. Rio de Janeiro: Contraponto, 2008, p. 431-513.

VIVEIROS DE CASTRO, E. Metafísicas canibais. São Paulo: Cosac e Naify; n -1, 2015.

SPINOZA, B. Ética. Belo Horizonte: Autêntica Editora, 2007.

Marcio José de Araujo Costa

Professor do Programa de Pós-graduação em Psicologia da Universidade Federal do Maranhão (UFMA)

E-mail: costa.marcio@ufma.br 